\author{
Amila Puzić \\ Nastavnički fakultet Univerziteta »Džemal Bijedić« u \\ Mostaru, Odsjek likovne umjetnosti / Džemal Bijedić \\ University of Mostar, Faculty of Education, Department \\ of Art History \\ Sjeverni logor bb, Mostar \\ amilapuzic@gmail.com \\ Izvorni znanstveni rad / Original scientific paper \\ UDK / UDC: 069.9(497.6 Sarajevo):7]"1997/1999" \\ DOI: 10.17685/Peristil.59.11 \\ 30. 8. 2016.
}

\section{Izložba kao socijalna intervencija - godišnje izložbe SCCA-Sarajevo: Meeting Point (1997.), Beyond the Mirror (1998.), Under Construction (1999.)}

Ključne riječi: javni prostor, izložba, site-specific, participacija, interakcija Keywords: public space, exhibition, site-specific, participation, interaction

U prilogu je riječ o umjetničkim praksama u javnom prostoru koje su između 1997. i 2000. godine realizirane u okviru Soroš centra za savremenu umjetnost (SCCA) Sarajevo u Bosni i Hercegovini. Analiza i interpretacija karakterističnih primjera odnosi se na tri godišnje izložbe u organizaciji SCCA-Sarajevo: »Meeting Point« (1997.), »Beyond the Mirror« (1998.) $i$ »Under Construction«(1999.).

Heterogene umjetničke prakse koje se krajem 1990-ih godina javljaju u Bosni i Hercegovini valja, prije svega, sagledati unutar naročitih ekonomskih, političkih, socijalnih i kulturnih okvira. Dok se u širem međunarodnom kontekstu emancipatorski potencijal kritičkih praksi 90-ih godina nerijetko ugrađuje u ustroj umjetničkih institucija doprinoseći širenju kulturnih utjecaja, srodna nastojanja u bosanskohercegovačkom kontekstu ne dijele ista polazišta ni iskustva. Fenomen koji se ogleda u afirmaciji nezavisnih kustoskih i umjetničkih kolektiva, udruženih u nevladine organizacije kao osnovne proizvodne jedinice, tako se ne može dovesti u povijesnu vezu s umjetničkim praksama u prijeratnoj $\mathrm{BiH}$.

Po završetku rata, ${ }^{1}$ godine 1996. u Sarajevu je otvoren Soroš centar za savremenu umjetnost (SCCA-Sarajevo), jedan od posljednjih u mreži od dvadesetak centara u zemljama srednje i istočne Europe u kojima je kao matična institucija djelovao fond Otvoreno društvo. Povjesničarka umjetnosti i voditeljica Centra Dunja Blažević navodi sljedeće: »U odnosu na predratni, poslijeratni umjetnički život bitno je reduciran i osiromašen u materijalnom, institucionalnom $\mathrm{i}$ profesionalnom smislu. Vraćanje u 'normalan' život disciplinira umjetnost, vraća je na njeno mjesto, u galerije, muzeje, akademije, ateljee. Međutim, iza privida normalnosti postoji vakuum - predratna infrastruktura razorena je fizički, kao i sistem umjetnosti (financiranje institucija, baštine...). Nema znakova uspostavljanja novog sistema; uslovi za stvaranje umjetničkog tržišta, mecenstva, ili drugih oblika održavanja umjetnosti u životu, ne postoje. Država još uvijek živi od donacija iz inostranstva, za umjetnost i kulturu ne preostaje gotovo ništa. Mučni proces tranzicije, koji još uvijek traje u zemljama Centralne i Istočne Evrope, u ratom razorenoj, podijeljenoj i politički blokiranoj BiH nije ni započeo. «2

Centar je u fokusu imao neke od najakutnijih problema suvremene umjetnosti u postratnom vremenu u $\mathrm{BiH}$ : premošćivanje informacijskog jaza i odnosa centar - pe- 
riferija, tj. povezivanje sa svijetom i razmjenu informacija, uspostavljanje veze s bosanskohercegovačkim umjetnicima $\mathrm{u}$ dijaspori, formiranje nove umjetničke scene, tj. lansiranje novih prijedloga i projekata koji će okupiti i usmjeriti raspršenu kreativnu energiju i dati financijsku i organizacijsku potporu individualnim i skupnim pojavama koje u lokalnoj sredini nisu prepoznate ni priznate kao umjetnost. ${ }^{3}$ Slijedeći ove ciljeve, Centar je započeo s konceptom godišnjih izložbi koje su realizirane u razdoblju od 1997. do 2000. godine.

\section{Meeting Point, Beyond the Mirror i Under Construction kao site-specific umjetnička praksa}

Godišnje izložbe u organizaciji SCCA - Meeting Point, Beyond the Mirror i Under Construction - u širem smislu predstavljaju primjere site-specific umjetničke prakse. Izložbe su bile koncipirane na različit način, ali su u zajedničkom fokusu imale dokidanje umjetničkih konvencija i »ograničenja unutar tradicionalnih medija i izlagačkih praksi. Izložba Meeting Point (24. srpnja - 12. rujna 1997.) bila je koncipirana kao tromjesečna umjetnička radionica u povijesno i arhitektonski specifičnom kontekstu ljetne bašte »Ćulhan", smještene u ruševinama turskog hamama iz 16 . stoljeća na Baščaršiji. Inicijativu za izložbu pokrenula je skupina mladih umjetnika okupljenih oko Centra, a izložba je uključivala suradnju s regionalnim i međunarodnim umjetnicima, kustosima, teoretičarima i kritičarima umjetnosti koji su pozvani da sudjeluju u pratećem programu, u sklopu kojeg je prikazana suvremena inozemna produkcija autorskog videa. Kustosica izložbe bila je Dunja Blažević, kustosice suradnice Lejla Hodžić i Enes Zlatar, a na izložbi je sudjelovalo 55 umjetnika. Ovom izložbom nastojao se uspostaviti novi žanr urbano orijentiranih izložbi, a cjelokupni projekt predstavljao je neku vrstu eksperimenta koji je propitivao (sam) prostor, kao i mogućnosti interakcije i participacije.

Izložba Beyond the Mirror (22. kolovoza - 20. rujna 1998.) konceptualno je mišljena na drugačiji način, prije svega zbog činjenice da se događala u sklopu 4. Sarajevo Film Festivala koji je bio usmjeren na proizvodnju i (re)prezentaciju sadržaja u okviru filmskog medija, kao i zbog činjenice da su radovi izlagani na različitim lokacijama, od kojih je svaka zahtijevala poseban pristup. Riječ je bila o izvaninstitucionalnom djelovanju ${ }^{5}$ u nekonvencionalnim izlagačkim prostorima poput kafića, knjižara, mostova. Na izložbi su sudjelovala 34 umjetnika, a obuhvaćala je 17 videoradova, sedam videoinstalacija, 22 site-specific rada i tri performansa. U pratećem programu sudjelovali su regionalni i međunarodni umjetnici. $^{6}$

Kustosica Dunja Blažević pojašnjava kako je sam naziv izložbe trebao uputiti na upotrebu »novih« medija i tehno- logija što se može tumačiti kao zahtjev za većom demokratizacijom umjetnosti koji je u to vrijeme predstavljao jedan od osnovnih ciljeva Centra. "Naslov izložbe preuzet je od Lewisa Carrolla kako bi ponudio prostor za različite interpretativne mogućnosti, ali se prije svega odnosi na pokušaj da se istraži priroda umjetničkog medija (prije svega videa) i priroda same umjetnosti. Prolazeći kroz ogledalo, kroz tu površinu koja reflektira našu vlastitu sliku, mi stupamo u prostor unutarnjeg, subjektivnog svijeta i njegovih slika vječne teme svake umjetnosti. S druge strane, nove tehnologije, posebno elektronički mediji - koji mogu biti shvaćeni kao nova metafora starog 'ogledala', otvaraju niz pitanja: vjerodostojnosti virtualne slike, simulakruma, refleksije (spektra). Ono što imamo na djelu je, dakle, stvaranje usporednog svijeta virtualne stvarnosti. Granica između subjektivnog i objektivnog pogleda na svijet, kao i svijest o bivanju ovdje i sada na taj način biva dokinuta ... " $^{7}$

Under Construction (23. srpnja - 23. rujna 1999.) naziv je treće i posljednje izložbe koju je organizirao SCCA pod kustoskim vodstvom Dunje Blažević, a vezana je uz Umjetničku galeriju Bosne i Hercegovine koja je u tom razdoblju bila pod rekonstrukcijom, ${ }^{8}$ na što se referira i sam naslov. Na fasadi Umjetničke galerije radove je realiziralo 16 umjetnika, a umjetnički radovi sukcesivno su se smjenjivali za vrijeme trajanja izložbe. Dunja Blažević navodi da se sadržaj izložbe primarno odnosio na uspostavljanje dijaloga između onoga što se nalazilo u unutrašnjosti Galerije - najveća umjetnička zbirka radova od nacionalnog značenja - i onoga što se događalo "vani« privremene umjetničke intervencije i procesi. Na ovaj način formalna struktura muzeja »suprotstavljena« je neformalnoj strukturi "mobilnoga « umjetničkog centra (SCCA). ${ }^{9}$

Konceptualna poveznica godišnjih izložbi može se prepoznati u djelovanju umjetnika koje je bilo usmjereno na "stvarni « prostor i na "stvarne « ljude, bez obzira na pojedinačne lokacije na kojima su radovi realizirani i bez obzira na osobite teme i probleme na koje su nastojali skrenuti pozornost. Mogu se izdvojiti tri formalno-sadržajne skupine radova: participativni i interaktivni radovi kojima je ostvaren naročit odnos između »mjesta «i publike, kontekstualni radovi kojima je ostvaren suodnos između publike i povijesnih značajki mjesta te radovi koji su iskazali svojevrsni društveno-politički angažman.

\section{Participativni i interaktivni radovi}

Za izložbu Meeting Point Izeta Građević realizirala je rad Bez naziva (sl. 1) koji se u sadržajnom smislu nije referirao na povijesne značajke »Ćulhana«, ali je formom site-specific instalacije slijedio njegove arhitektonske karakteristike. Instalacija se sastojala od zapisa različitih zvukova grada i 

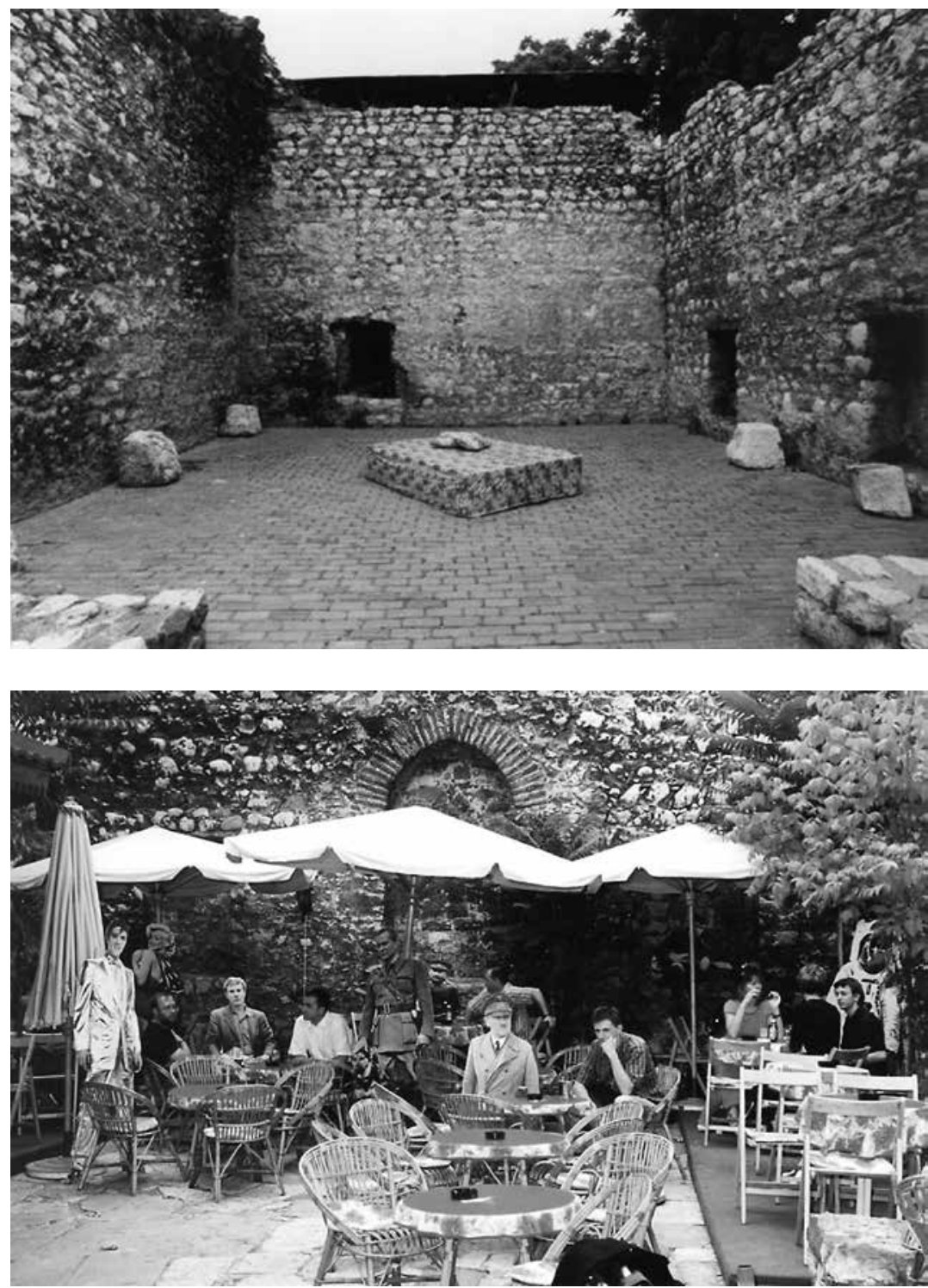

1. Izeta Građević, Bez naziva, Prva godišnja izložba Meeting Point, ljetna bašta "Ćulhan «, Sarajevo, 29. srpnja - 3. kolovoza 1997. (ljubaznošću SCCA-Sarajevo) / Izeta Građević, Untitled, First Annual Exhibition Meeting Point, Summer Garden Culhan, Sarajevo, 29 July - 3 August 1997 (courtesy of SCCA Sarajevo)

2. Trio, Meetings, Prva godišnja izložba Meeting Point, ljetna bašta »Ćulhan«, Sarajevo, 24.-30. srpnja 1997. (ljubaznošću SCCA-Sarajevo) / Trio, Meetings, First Annual Exhibition Meeting Point, Summer Garden Ćulhan, Sarajevo, 24-30 July 1997 (courtesy of SCCA Sarajevo)

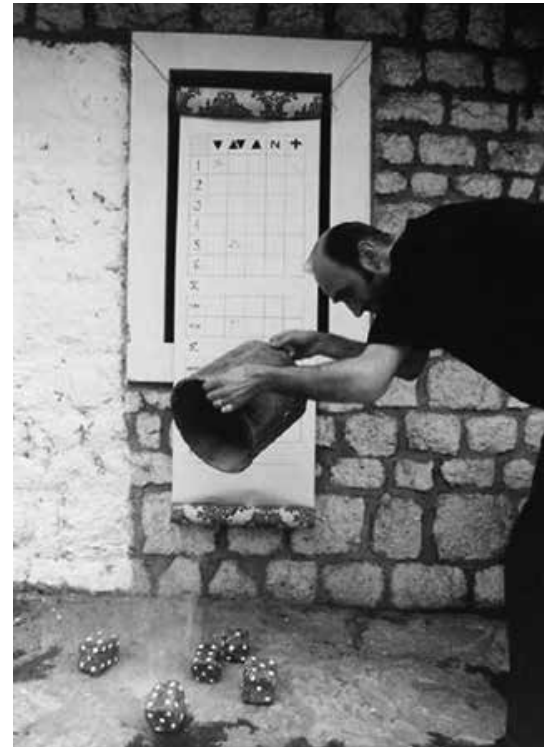

3. Kurt i Plasto, Zaboravljena ratna igra, koja je zaboravljena, Prva godišnja izložba Meeting Point, ljetna bašta »Ćulhan«, Sarajevo, 4.-9. kolovoza 1997. (ljubaznošću SCCA-Sarajevo) / Kurt \& Plasto, The forgotten war game, that was forgotten, First Annual Exhibition Meeting Point, Summer Garden Culhan, Sarajevo, 4-9 August 1997 (courtesy of SCCA Sarajevo)

funkcionirati tek nakon što se uključi publika kojoj je prepušteno da odluči je li riječ o instalaciji, skulpturi ili pak o običnom madracu kao mjestu za odmor, sjedenje i slušanje zvučnih zapisa.

Umjetnička skupina Trio (Bojan i Dada Hadžihalilović) postavila je instalaciju Meetings u kafiću ljetne bašte, a sastojala se od papirnatih figura $u$ prirodnoj veličini, među kojima su se našli likovi iz popularne kulture, filma, rock'n'rolla ili politike (sl. 2). Posjetiteljima je omogućeno »druženje«s

madraca prekrivenog cvjetnim uzorkom. Madrac se referirao na »javno«, a cvjetna prostirka na privatno vlasništvo umjetnice, što je doprinijelo usložnjavanju značenja i poništavanju granica između javne i privatne sfere. Umjetnica ističe kako se rad bavi Sarajevom koje je lišeno povijesti, imenovanja i već institucionalizirane sentimentalnosti koja se veže uz njegovo ime. ${ }^{10} \mathrm{Za}$ zvučni portret Sarajeva Izeta Građević odabrala je poznate i svakodnevne zvukove koji su snimljeni na različitim lokacijama u gradu, a koje je reproducirala unutar razrušenih zidina "Ćulhana«. Rad počinje poznatim ličnostima te su oni koji su došli vidjeti izložbu ili popiti piće $u$ »Ćulhanu« dobili središnje mjesto u radu, dok su se umjetnici odrekli kontrole nad sadržajem koji su "predstavili«.

Fokus na participaciji, ali bez primjesa intimne, privatne sfere, uočava se u instalaciji Zaboravljena ratna igra, koja je zaboravljena Kurta i Plaste (sl. 3). Instalacija je osmišljena kao nesvakidašnje igranje »jamba (društvene igre koja se često igrala u ratu) i funkcionirala je isključivo u interakciji s publikom. Posjetitelji su, zajedno s umjetnicima, 
imali priliku okušati sreću bacajući kockice, napravljene od kaldrme zatečene in situ, koje su zamijenile obične igraće kocke, a postignuti rezultati upisivali su se na obližnju tablu. Instalacija se odnosila prema specifičnom mjestu računajući na izvedbu koja se događa »ovdje i sada«, ne referirajući se na povijesnu specifičnost mjesta, ali aludirajući na netom završenu opsadu koja je uvelike odredila i promijenila svakodnevicu. Na ovaj način, kroz najobičniju igru, ponovno je, makar privremeno, uspostavljena zona javnosti na koju su umjetnici računali. Zaboravljena ratna igra, koja je zaboravljena otvara mogućnost različite percepcije vremena i računa na gledatelja i njegovu participaciju te konstantno sudjelovanje publike - slučajnih prolaznika - i funkcionira na relacijskom nivou te dokida fenomenološki pristup recepcije umjetničkog procesa.

Ilustrirani primjeri potvrđuju jednu od osnovnih premisa novog žanra javne umjetnosti, ${ }^{11}$ a koja se odnosi na zaokret u proizvodnji umjetnosti u javnom prostoru koja je uvjetovana kompleksnom mrežom socijalnih odnosa unutar određene zajednice, a ne mjestom u kojem ili naspram kojeg nastaje. Umjetnici su ovakvim pristupom, prije svega, nastojali osnažiti publiku uključujući je direktno u proces(e) produkcije rada, ali nadasve (pre)usmjeravajući tradicionalan odnos između umjetničkog djela i publike na participativne procese. Time je fokus izmješten $s$ umjetnika na recipijenta, s objekta na proces umjetničke proizvodnje, s produkcije na recepciju, i istaknuta je važnost direktne, neposredne interakcije.

\section{Kontekstualni radovi}

Riječ je o radovima koji su se na specifičan način odnosili prema povijesnim i simboličkim značajkama nekadašnjega turskog hamama. Umjetnici su se referirali na politički, društveni, prostorni i povijesni kontekst te pokušali naći odgovarajuća sredstva i načine materijalizacije umjetničkog sadržaja izvan tradicionalnoga likovnog jezika. Ova strategija u krajnjoj liniji rezultirala je demokratizacijom umjetničkog polja:»U tom, po svojoj namjeni, demokratskom ambijentu uspostavio se i prirodniji, rav-

4. Eldina Begić, Meeting Point, Prva godišnja izložba Meeting Point, ljetna bašta »Culhan", Sarajevo, 3.-6. kolovoza 1997. (ljubaznošću SCCA-Sarajevo) / Eldina Begić, Meeting Point, First Annual Exhibition Meeting Point, Summer Garden Ćulhan, Sarajevo, 3-6 August 1997 (courtesy of SCCA Sarajevo) nopravniji odnos umjetnik - publika, budući da medijator u toj relaciji - djelo/rad - gubi svoje tradicionalne umjetničke karakteristike i komunikacijski kod nije više ograničen jezikom umjetnosti. Ulazak umjetnosti u prostor svakodnevnog života, njena nedidaktičnost i nepretencioznost - ne mijenjamo svijet, samo želimo postati dio tog svijeta - osnovna je strategija i poruka današnje umjetnosti, kojoj pripada i ono što smo nazvali MEETING POINT.«12

Eldina Begić bosanskohercegovačkoj se publici prvi put predstavila u »Ćulhanu « instalacijom pod nazivom Meeting Point (sl. 4), kojom se na vrlo suptilan, gotovo meditativan način poigrala s prvobitnom namjenom hamama u kojem se nekad zagrijavala voda. Umjetnica je u japanskoj tehnici origami izradila 40 pingvina koje je grupirala oko imaginarne vode, uspostavljajući simboličku revitalizaciju povijesno »ispražnjena« mjesta.

Prema istoj povijesnoj tematici hamama odnosili su se radovi nekoliko umjetnika srednje i starije generacije. Edin Numankadić u sklopu Meeting Pointa izložio je Tragove (sl. 5) kojima je nastojao oživjeti duh Mediterana: »Numankadić, koji u zadnje vrijeme postaje svojevrsni analitičar stvari koje su se vremenom sabrale u njegovom ateljeu, učinio je to asamblažom od morskog kamenja upakovanog između stakla i ogledala, $s$ tim što je okosnica djela tekst - citat, već do sada ispisivan na nekim drugim djelima; citat koji, mada uzet iz Musilovog dnevnika za 1918, izražava i za nas aktuelni komentar. $\aleph^{13}$ Duhovna pobjeda je u pravom smislu riječi strašnija od pobjede izvojevane oružjem, rečenica je koju je umjetnik preuzeo iz Musilova dnevnika, aludirajući kako ona, zajedno s ostalim predmetima zatečenim u atelijeru, predstavlja njegovu rijetku vezu s vanjskim svijetom $\mathrm{i}$ »bivšim« životom. »Tragovi su materijalizirano pamćenje. Morski oblutci postavljeni na stari kameni zid 'Ćulhana' spoj su dva pamćenja, ili dva elementa nastala u dva prirodnokulturna konteksta. «14

Instalacija Sahan (sl. 6) Salima Obralića bila je inspirirana tradicijom baščaršijskog zanatstva. Umjetnik je napravio

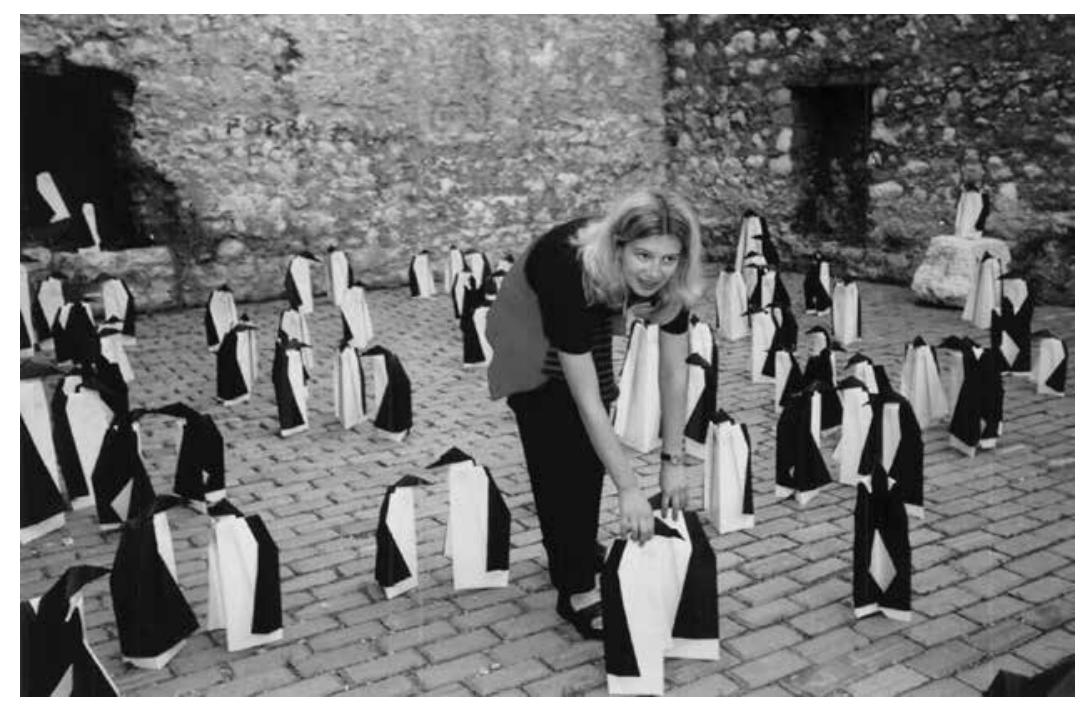



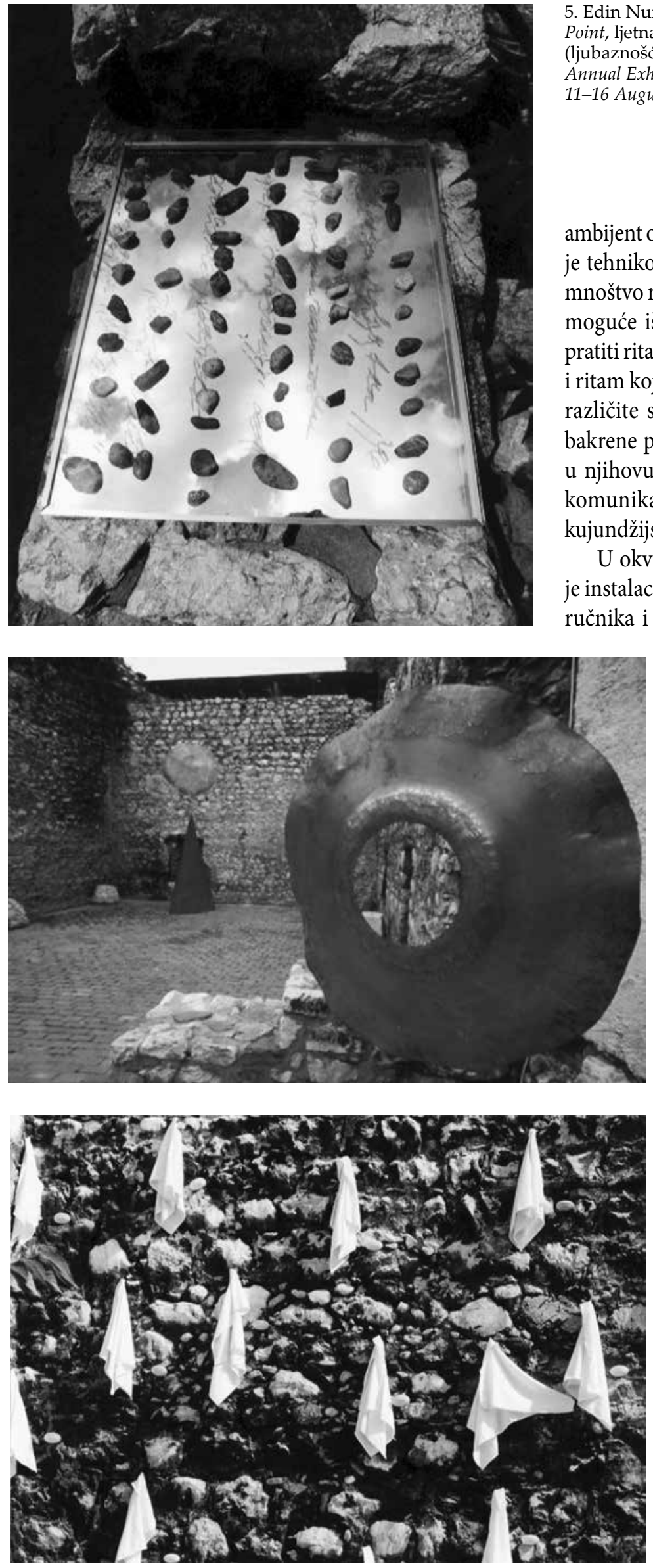

5. Edin Numankadić, Tragovi, Prva godišnja izložba Meeting Point, ljetna bašta »Ćulhan«, Sarajevo, 11.-16. kolovoza 1997. (ljubaznošću SCCA-Sarajevo) / Edin Numankadić, Traces, First Annual Exhibition Meeting Point, Summer Garden Ćulhan, Sarajevo, 11-16 August 1997 (courtesy of SCCA Sarajevo)

ambijent od okruglih i trougaonih bakrenih ploča po kojima je tehnikom savata urezao kaligrafske znakove, ponudivši mnoštvo različitih asocijacija i interpretacija: »Tu je još bilo moguće iščitavati simboličke i psihološke oznake kruga, pratiti ritam pulsacija koje su isijavali usjeci u bakreno tkivo i ritam koji su nametnule spoljnje okolnosti: vjetar, refleksi različite svjetlosti, pa i prateća muzika. « ${ }^{15}$ Postavljajući bakrene ploče u prostor "Ćulhana«, Obralić sahane vraća u njihovu "prirodnu« sredinu, istodobno uspostavljajući komunikaciju s obližnjom ulicom u kojoj su smještene kujundžijske radionice.

U okviru izložbe Meeting Point Nusret Pašić realizirao je instalaciju Bez naziva (sl. 7) koja se sastojala od 50 bijelih ručnika i isto toliko raznobojnih sapuna postavljenih na zidove »Ćulhana«, a osobit, gotovo performativan element, predstavljao je miris sapuna. Pašićev rad direktno se referirao na nekadašnju funkciju objekta, kao i na ritual čišćenja tijela i pročišćenja duha koji je bio predstavljen simbolikom bijele tkanine.

Pašić je na Drugoj godišnjoj izložbi izveo site-specific instalaciju Mape labirinta (sl. 8). Instalacija je bila napravljena od mobilnih objekata koji su simulirali prostor dječjeg igrališta. Na sadržajnom planu umjetnik je ostao vjeran konceptu kojeg je više od desetljeća razvijao u slikarskom mediju - motiv strašila koji predstavlja stabljičastim izduženim licima, dok je na formalnom/izvedbenom planu računao na (naročite) karakteristike mjesta i site-specific pristupa.

6. Salim Obralić, Sahan, Prva godišnja izložba Meeting Point, ljetna bašta »Ćulhan «, Sarajevo, 16.21. kolovoza 1997. (ljubaznošću SCCA-Sarajevo) / Salim Obralić, Sahan, First Annual Exhibition Meeting Point, Summer Garden Ćulhan, Sarajevo, 16-21 August 1997 (courtesy of SCCA Sarajevo)

7. Nusret Pašić, Bez naziva, Prva godišnja izložba Meeting Point, ljetna bašta "Ćulhan «, Sarajevo, 5.11. kolovoza 1997. (ljubaznošću SCCA-Sarajevo) / Nusret Pašić, Untitled, First Annual Exhibition Meeting Point, Summer Garden Ćulhan, Sarajevo, 5-11 August 1997 (courtesy of SCCA Sarajevo) 


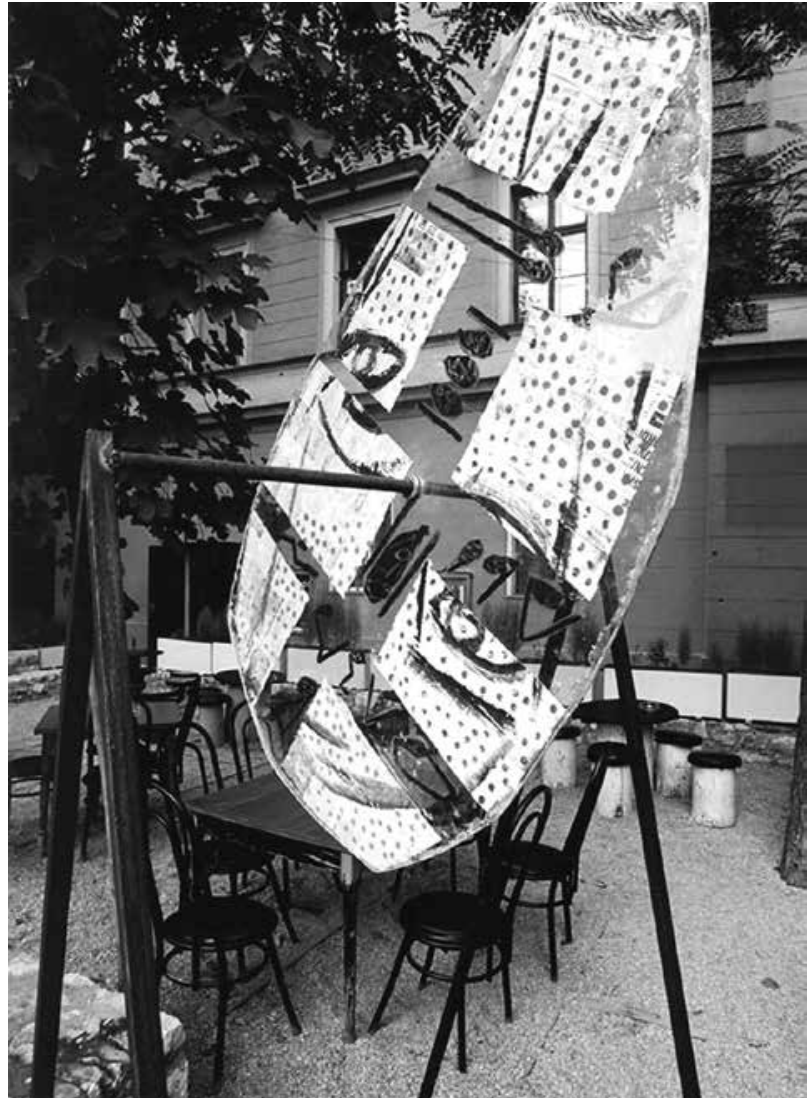

8. Nusret Pašić, Mape labirinta, Druga godišnja izložba Beyond the Mirror, Internet cafe, Sarajevo, 22. kolovoza - 20. rujna 1998. (ljubaznošću SCCA-Sarajevo) / Nusret Pašić, Maps-labyrinths, Second Annual Exhibition Beyond the Mirror, Internet Café, Sarajevo, 22 August - 20 September 1998 (courtesy of SCCA Sarajevo)

\section{Društveno angažirani radovi}

Obrise angažirane umjetničke prakse imaju radovi Gordane Anđelić Galić, Alme Suljević i Maje Bajević, umjetnica koje su sudjelovale na svim trima godišnjim izložbama i koje su na direktan način pristupile (re)prezentaciji društvenopolitičkih sadržaja.

Gordana Anđelić Galić na izložbi Beyond the Mirror ispred zgrade Akademije likovnih umjetnosti postavila je »kapiju» pod nazivom Kunst Macht Frei (sl. 9) kojom je

10. Alma Suljević, Poništavanje istine, Prva godišnja izložba Meeting Point, ljetna bašta »Culhan «, Sarajevo, 26.-30. kolovoza 1997. (ljubaznošću SCCA-Sarajevo) / Alma Suljević, Annulling truth, First Annual Exhibition Meeting Point, Summer Garden Ćulhan, Sarajevo, 26-30 August 1997 (courtesy of SCCA Sarajevo)

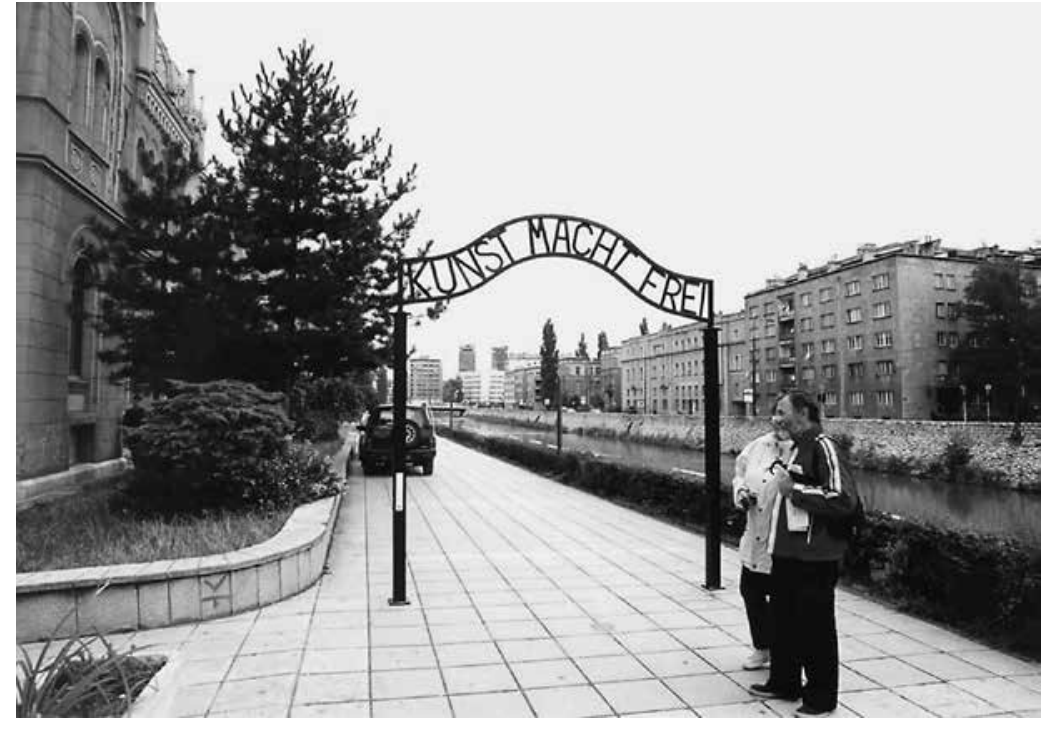

9. Gordana Anđelić Galić, Kunst Macht Frei, Druga godišnja izložba Beyond the Mirror, Akademija likovnih umjetnosti, Sarajevo, 22. kolovoza - 20. rujna 1998. (ljubaznošću SCCASarajevo) / Gordana Anđelić Galić, Kunst Macht Frei, Second Annual Exhibition Beyond the Mirror, Academy of Fine Arts, Sarajevo, 22 August-20 September 1998 (courtesy of SCCA Sarajevo)

otvorila niz etičkih, socijalnih i političkih pitanja. Kunst Macht Frei priča je o »umjetničkim zatočenicima« koji su u nemilosti određena društveno-političkog sustava i njime

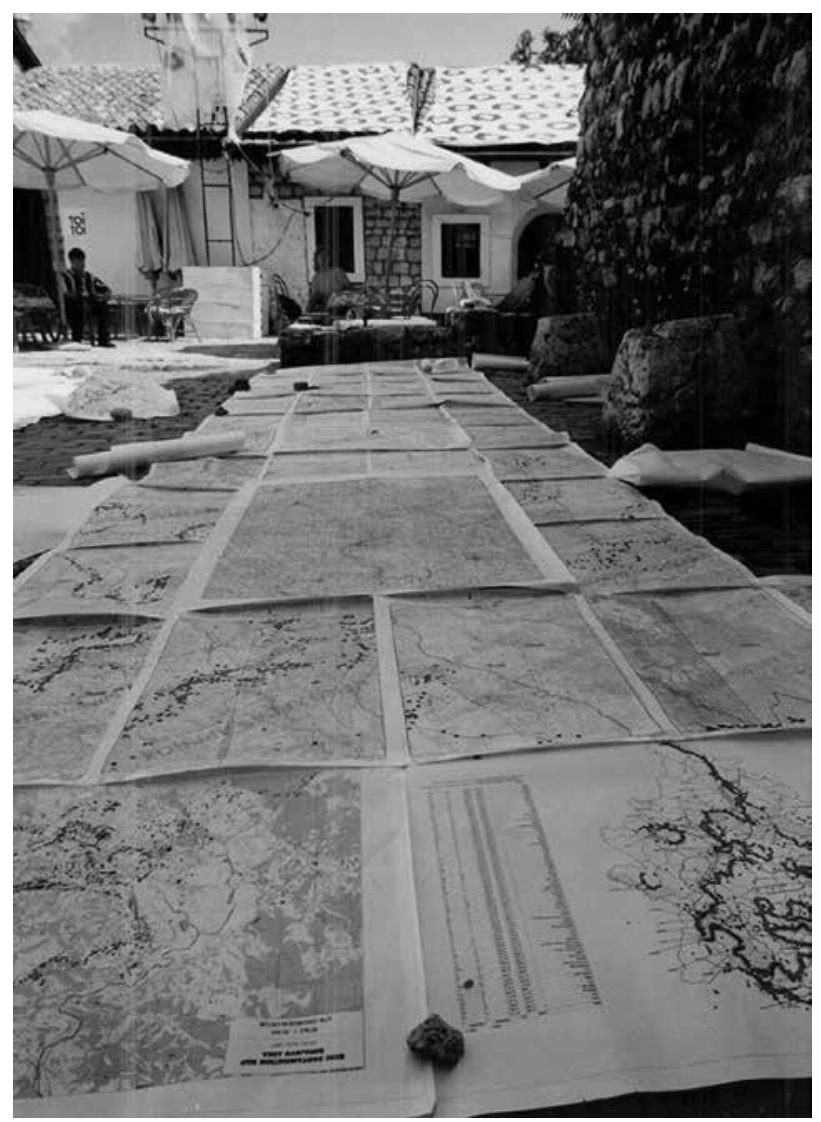




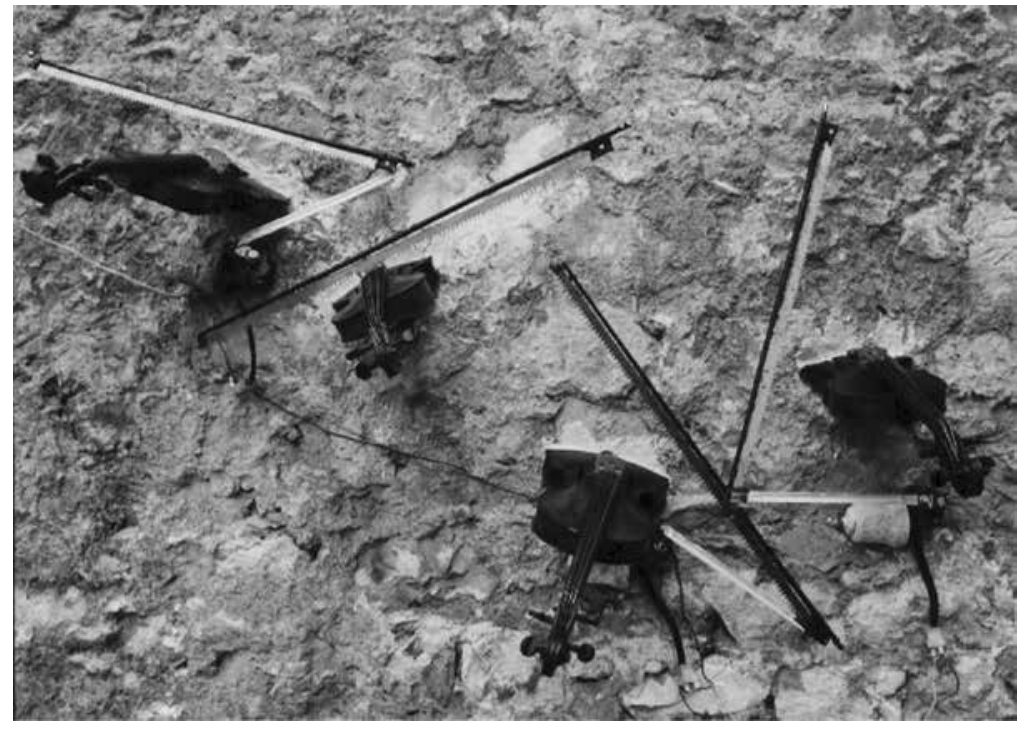

11. Maja Bajević, Meine Kleine Nachtmusik, Prva godišnja izložba Meeting Point, ljetna bašta »Ćulhan «, Sarajevo, 30. kolovoza - 12. rujna 1997. (ljubaznošću SCCA-Sarajevo) / Maja Bajević, Meine Kleine Nachtmusik, First Annual Exhibition Meeting Point, Summer Garden Ćulhan, Sarajevo, 30 August - 12 September 1997 (courtesy of SCCA Sarajevo)

su direktno uvjetovani. Natpis Kunst Macht Frei predstavlja direktnu aluziju na nacističke logore iz Drugoga svjetskog rata u koje se ulazilo kroz »kapiju « na kojoj je stajao natpis Arbeit Macht Frei (Rad oslobađa). Naslov rada može se

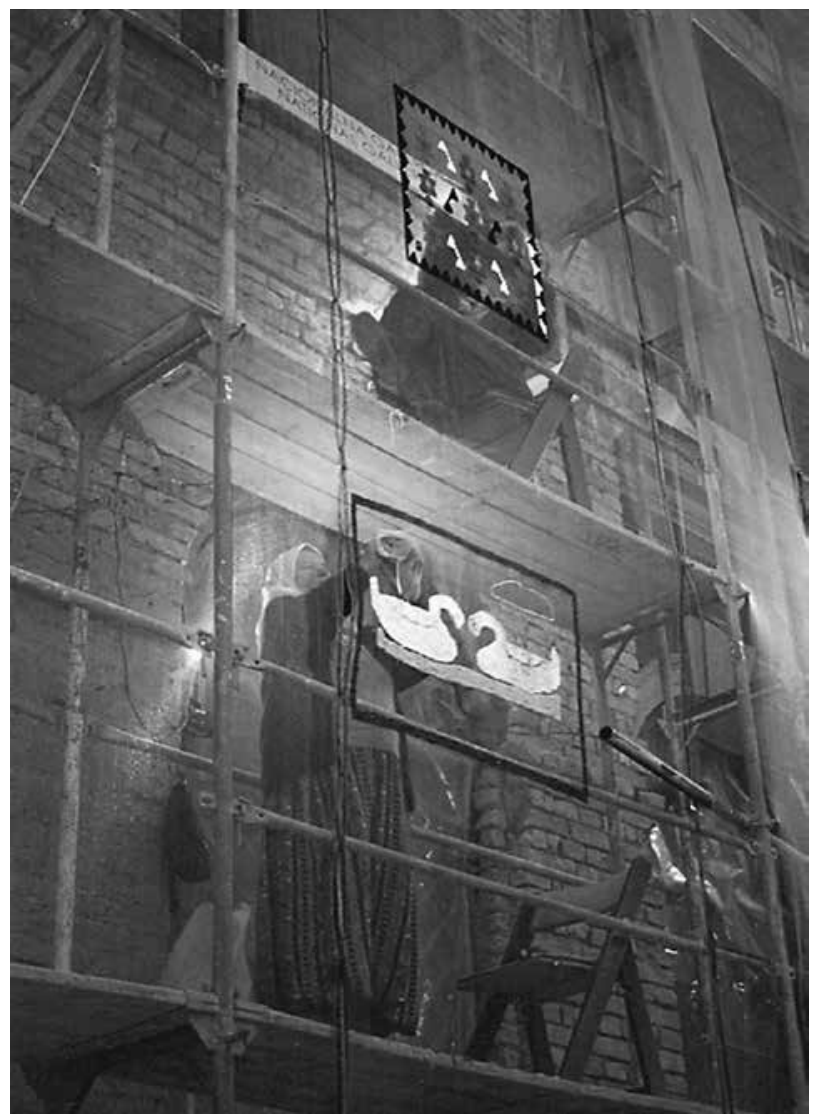

čitati i kao metafora mentalnog ali nadasve materijalnog logora u kojem umjetnici danas žive i u kojem nisu pošteđeni od ekonomskih i društveno-političkih procesa i njihovih implikacija. Rad se također referira na sve veću ekspanziju umjetničkog tržišta koje uvjetuje sustav proizvodnje i reprezentacije suvremene umjetnosti.

Potaknuta činjenicom da u poslijeratnoj Bosni i Hercegovini postoje brojna minska polja, ${ }^{16}$ Alma Suljević na svim se trima godišnjim izložbama, različitim medijima i različitim odgovorima na »zahtjeve« mjesta, odnosila prema istoj tematici. Umjetnica je u sklopu izložbe Meeting Point realizirala prvi rad unutar ove serije - interaktivnu instalaciju Poništavanje istine (sl. 10) kojom je simboličkim uklanjanjem mina s originalnih minskih mapa pokušala poništiti dokaze o njihovu postojanju. Ona je na mapama ritualno ispisivala vlastita traumatična iskustva i sjećanja, zaokruživala kuće u kojima su živjeli njezini prijatelji i poznanici. Provocirajući diskusiju o mjestu traume, umjetnica je site-specific djelovanje prevela u angažiranu refleksiju na postratnu stvarnost.

Maja Bajević je na Meeting Pointu realizirala Meine Kleine Nachtmusik (Moja mala noćna muzika) (sl. 11), audioinstalaciju s gudalima koje pokreću elektromotori $\mathrm{i}$ »tijelima« violina koja su "provirivala« iz zidova »Ćulhana«. Zvučnu kulisu činio je glas koji imitira zvuk violine, bombardera i zavijanja. Instalacija je istodobno na suptilan (krhka tijela violina) i agresivan (zvuk bombardera i zavijanja koja proizvode elektromotori) način upućivala na netom završeni rat $\mathrm{i}$ simulirala zvučnu kulisu koja je predstavljala svakodnevicu građana Sarajeva.

Nakon ove instalacije koja nije računala na direktnu participaciju posjetitelja, Bajević je u sklopu Beyond the Mirrora izložila dva videorada koji su, svaki na svoj način, pozivali na interakciju. Videorad Govornik bio je postavljen poput komercijalne reklame na jedan od središnjih billboarda u gradu. Između propagandnih poruka pojavljuje se video na kojem nam se obraća nepostojeći političar koji nam govori a da nam ništa ne kaže. Rad se, prije svega, kritički odnosio prema demagoškim »propovijedima« političara. Pored toga

12. Maja Bajević, Women at work, Treća godišnja izložba Under Construction, fasada Umjetničke galerije Bosne i Hercegovine, Sarajevo, 1.-5. rujna 1999. (ljubaznošću SCCA-Sarajevo) / Maja Bajević, Women at work, Third Annual Exhibition Under Construction, façade of the Art Gallery of Bosna and Herzegovina, Sarajevo, 1-5 September 1999 (courtesy of SCCA Sarajevo) 
što je računao na interakciju sa slučajnim prolaznicima, rad je također otvorio pitanje politizacije umjetničke sfere koja proizvodi i problematizira (one) sadržaje koji su izostali iz društvene sfere i sfere realpolitike kojoj zapravo pripadaju.

$\mathrm{Na}$ Trećoj godišnjoj izložbi Maja Bajević na fasadi je Umjetničke galerije BiH izvela intervenciju Woman at work. Riječ je o participativnom projektu ${ }^{17} \mathrm{u}$ kojem je sudjelovalo pet žena iz Srebrenice koje su, zajedno s umjetnicom, na skelama Umjetničke galerije $\mathrm{BiH}$ vezle različite simbole iz profanog života (sl. 12). Tradicionalni »ženski« rad koji se veže uz privatnu sferu tako je izmješten u javni prostor - »na skelu«, koja se tradicionalno veže za posao koji obavljaju muškarci. Osim iznimno važnog pitanja ženskog rada i podjele spolnih i rodnih uloga, važno je primijetiti kako je riječ o izrazito političnom aktu, s obzirom na to da je riječ o ženama koje dolaze iz visokotraumatizirana područja u kojem je počinjen najveći genocid u recentnoj europskoj povijesti. Ovaj primjer pokazuje kako se u okviru participacijske prakse računa nadilaženje individualnog autorstva nauštrb kreiranja prostora i uvjeta za oslobađanje kreativnosti drugih, pri čemu umjetnik preuzima facilitatorsku ulogu u poticanju koautorstva u zajednici. ${ }^{18} \mathrm{Kada}$ su posrijedi ovakve prakse, ipak, ostaje otvoreno pitanje na koji način i kako umjetnost $\mathrm{i}$ umjetnici $»$ rade «s pojedinim zajednicama, koje su njihove ingerencije i mogućnosti te u kojoj mjeri ovakve umjetničke prakse postaju surogati za »stvarne« političke i društvene akcije. Umjetnost, sama po sebi, ne raspolaže alatima koji dugoročno mogu riješiti socijalne i političke probleme unutar određene zajednice, ali može doprinijeti njihovoj boljoj artikulaciji i vidljivosti u javnosti.

\section{Zaključak}

Postratna situacija proizvela je mnogostruke reakcije kod umjetnika koji su iznova pokušali prisvojiti javni prostor nakon 1460 dana opsade. U ovom razdoblju u Bosni i Hercegovini očituje se visok stupanj konflikta kojim je određena javna sfera unutar koje umjetnost postaje (jednom) mogućom strategijom obrane javnog prostora. Razmatrane izložbe u organizaciji Soroš centra za savremenu umjetnost u Sarajevu dokinule su granice izlaganja u lokalnom kontekstu pa su tako tradicionalne izložbene forme zamijenjene »novim« izlagačkim praksama. Težnja $\mathrm{k}$ (re)aktivaciji društvene uloge umjetnosti, a ne demokratizaciji umjetničkog čina po sebi, bila je također motivirana poslijeratnom umjetničkom i izlagačkom praksom koja je iznova pokušala disciplinirati umjetnost i vratiti je u akademske okvire.

Aktivnosti o kojima je bilo riječi ne treba promatrati kao puko popunjavanje "pukotina» sustava iako su često obavljale posao koji su institucije (zbog različitih i veoma kompleksnih razloga) u znatnoj mjeri zanemarivale. Stoga, prisvajanje institucionalne uloge od samoorganiziranih kustoskih i umjetničkih kolektiva ne služi samo kao korektor kulturnog polja kojeg su prije ispunjavale javne/državne institucije nego je riječ o uspostavi drugačijeg modela kritičkog djelovanja koji nije lišen vlastitih kontradiktornosti i neuspjeha. Nakon povlačenja Soroša 2000-ih godina, evidentna je promjena aktivnosti, načina djelovanja i upravljanja Centrom koji danas ovisi o privremenim grantovima i koji je primoran na sklapanje savezništava na institucionalnom i izvaninstitucionalnom planu te predstavlja temu kojom se tek valja pozabaviti.

\section{BILJEŠKE}

1 Agresija na Bosnu i Hercegovinu započela je 6. travnja 1992., a rat je okončan potpisivanjem mirovnog sporazuma u Daytonu 21. studenoga 1995. godine.

2 DUNJA BLAŽEVIĆ, Oni dolaze, u: Maxumim, katalog izložbe, Centar za savremenu umjetnost, Sarajevo, 2000., 3-4.

3 Ibid.

4 Miwon Kwon drži da se cjelokupna geneza javne umjetnosti može promatrati pomoću triju paradigmi unutar tridesetpetogodišnje povijesti pokreta javne umjetnosti, naročito u SAD-u: fenomenološka, socijalna/institucionalna i diskurzivna. Unatoč činjenici da su donekle kronološki prezentirane, Kwon upozorava da ove paradigme ne predstavljaju platforme u određenoj linearnoj trajektoriji povijesnog razvoja. Prva je umjetnost na javnim mjestima, a odnosi se na modernističku apstraktnu skulpturu postavljenu u cilju dekoracije ili oživljavanja urbanih prostora. Ovom paradigmom mjesto se promatra isključivo kao fizički, arhitektonski identitet koji je u funkciji postamenta za skulpturu. Druga je umjetnost kao javni prostor, karakteriziraju je izrazito dizajnirane urbane skulpture koje imaju funkciju uličnog namještaja, arhitektonske konstrukcije ili pejzažnog okoliša. Treću paradigmu predstavlja umjetnost u javnom interesu (novi žanr javne umjetnosti) i podrazumijeva umjetničke prakse koje djeluju u cilju artikulacije određena javnog interesa. Riječ je o praksi koja se najčešće odnosi na djelovanje unutar određene zajednice te se javni prostor ne promatra kao formalni ili fenomenološki okvir nego radije kao medij - prostor "podruštvljavanja« koji nastaje interakcijom sa zajednicom: MIWON KWON, One Place After Another: Sitespecific Art and Locational Identity, MIT Press, Cambridge, Mass., 2004., 60 (prevela A. P.).

5 Treba upozoriti kako izlazak u javni prostor ne treba isključivo tumačiti kao izvaninstitucionalno, kritičko djelovanje u smislu zauzimanja kontrapozicije, nego da je riječ bila o reverzibilnom procesu u kojem je izlazak $\mathrm{u}$ javni prostor istodobno bio uvjetovan nepostojanjem (tih istih) institucija koje bi ovakve prakse prepoznale i legitimirale. Ovaj "problem«, u svakom slučaju, ostaje otvoreno mjesto koje iziskuje detaljnije proučavanje i elaboraciju.

6 Dalibor Martinis (Zagreb) realizirao je videoinstalaciju u Galeriji Obala Art Centar (22. kolovoza - 20. rujna 1998.), Marie Jose Burki (Ženeva/Bruxelles) izložila je videoinstalaciju u prostorijama Galerije Akademije likovnih umjetnosti (25. kolovoza - 20. rujna 1998.) i Lala Raščić (Zagreb) izvela je niz akcija na različitim lokacijama (22. kolovoza - 20. rujna 1998.). Aktivnosti Centra ovom izložbom bile su usmjerene i na osnaživanje vlastite umjetničke produkcije, što će u nastavku postati jedna od primarnih aktivnosti Centra, te je u sklopu 4. Sarajevo Film Festivala (28. kolovoza 1998.) predstavljeno 17 videoradova produciranih u sklopu ove izložbe.

7 DUNJA BLAŽEVIĆ, Beyond the Mirror, URL: http://scca.ba/exhibitions/annual-exhibitions/beyond-the-mirror/ (17. 3. 2016.).

8 Rekonstrukcija i »rehabilitacija« razrušenih objekata ovisila je o stranim financijerima, odnosno donatorima, što je umjetnicima otvorilo prostor za dodatnu kritičku refleksiju. 
9 DUNJA BLAŽEVIĆ, Under Construction, URL: http://scca.ba/exhibitions/annual-exhibitions/under-construction-oprez-radovi/ (18. 3. 2016.). 10 IZETA GRAĐEVIĆ, Bez naziva / Untitled, u: Meeting Point. Prva godišnja izložba, katalog izložbe, Soros centar za savremenu umjetnost, Sarajevo, 1998., bez pag.

11 Odnosi se na treću paradigmu umjetnosti u javnom prostoru. MIWON KWON (bilj. 4), 60.

12 DUNJA BLAŽEVIĆ, Predgovor, u: Meeting Point. Prva godišnja izložba, katalog izložbe, Soros centar za savremenu umjetnost, Sarajevo, 1998., bez pag.

13 MELIHA HUSEDŽINOVIĆ, [nenaslovljeno], u: Meeting Point. Prva godišnja izložba, katalog izložbe, Soros centar za savremenu umjetnost, Sarajevo, 1998., bez pag.

14 EDIN NUMANKADIĆ, Tragovi / Traces, u: Meeting Point. Prva godišnja izložba, katalog izložbe, Soros centar za savremenu umjetnost, Sarajevo, 1998., bez pag.

15 SALIM OBRALIĆ, Sahan, u: Meeting Point. Prva godišnja izložba, katalog izložbe, Soros centar za savremenu umjetnost, Sarajevo, 1998., bez pag.

$16 \mathrm{U}$ trenutku nastanka rada, prema statističkim podacima, u BiH postoji tri milijuna mina.

17 Claire Bishop navodi kako upotreba termina "projekt« kojim se od 90-ih godina sve češće zamjenjuje riječ umjetničko djelo, ima dvosmislen status te kako za autore/kustose ima više socijalno nego estetsko značenje. Riječ projekt zamjenjuje termin umjetničko djelo da bi opisala dugoročni umjetnički pothvat u društvenoj sferi te se od 90 -ih godina ovaj termin upotrebljava kako bi se njime opisale različite vrste umjetničkog angažmana: kolektivne prakse, samoorganizirane aktivističke grupe, transdisciplinarna istraživanja, participativne i društveno angažirane umjetničke prakse, kao i eksperimentalno kuriranje: CLAIRE BISHOP,
Artificial Hells. Participatory Arts and the Politics of Spectatorship, Verso, London-New York, 2012., 198-199 (prevela A. P.).

18 Ibid., 188 (prevela A. P.).

\section{REFERENCES}

CLAIRE BISHOP, Artificial Hells. Participatory Arts and the Politics of Spectatorship, Verso, London-New York, 2012.

DUNJA BLAŽEVIĆ, Predgovor, in: Meeting Point. Prva godišnja izložba, exhibition catalogue, Soros centar za savremenu umjetnost, Sarajevo, 1998, [s. p.].

DUNJA BLAŽEVIĆ, Oni dolaze, in: Maxumim, exhibition catalogue, Centar za savremenu umjetnost, Sarajevo, 2000, 3-4.

DUNJA BLAŽEVIĆ, Beyond the Mirror, URL: http://scca.ba/exhibitions/annual-exhibitions/beyond-the-mirror/ (17/03/16).

DUNJA BLAŽEVIĆ, Under Construction, URL: http://scca.ba/exhibitions/ annual-exhibitions/under-construction-oprez-radovi/ (18/03/16).

IZETA GRAĐEVIĆ, Bez naziva / Untitled, in: Meeting Point. Prva godišnja izložba, exhibition catalogue, Soros centar za savremenu umjetnost, Sarajevo, 1998, [s. p.].

MELIHA HUSEDŽINOVIĆ, [untitled], in: Meeting Point. Prva godišnja izložba, exhibition catalogue, Soros centar za savremenu umjetnost, Sarajevo, 1998, [s. p.].

MIWON KWON, One Place After Another: Sitespecific Art and Locational Identity, MIT Press, Cambridge, Mass., 2004.

EDIN NUMANKADIĆ, Tragovi / Traces, in: Meeting Point. Prva godišnja izložba, exhibition catalogue, Soros centar za savremenu umjetnost, Sarajevo, 1998, [s. p.].

SALIM OBRALIĆ, Sahan, in: Meeting Point. Prva godišnja izložba, exhibition catalogue, Soros centar za savremenu umjetnost, Sarajevo, 1998, [s. p.].

\section{Summary}

Amila Puzić

Exhibition as Social Intervention: Annual SCCA-Sarajevo Exhibitions: "Meeting Point"(1997), "Beyond the Mirror" (1998), “Under Construction” (1999)

Heterogeneous art practices which emerged in Bosnia and Herzegovina in late 1990s must be considered primarily within the particular economic, political, social and cultural framework. While the emancipatory potential of international critical practices of the 1990s was frequently embedded in the activity of art institutions, thus contributing to the dissemination of cultural influences, similar endeavours in Bosnia and Herzegovina did not share identical starting points or experiences. Therefore the phenomenon of affirmation of independent curatorial and artistic collectives, joined in NGOs as basic creative units, cannot be historically associated to art practices in pre-war Bosnia and Herzegovina.

After the war, in 1996, Soros Center for Contemporary Art was founded in Sarajevo as one of the last to be opened in a network of some twenty centres in Central and East European countries which housed the Open Society Fund. Between 1997 and 2000, SCCA Sarajevo organized three annual exhibitions: "Meeting Point" (1997), "Beyond the Mirror" (1998) and "Under Construction" (1999). These exhibitions, in the broadest sense, indicated a shift in art production and affirmation of social and political aspects of artistic engagement. They marked a significant change of exhibition practices, in which traditional forms were replaced by "new" art practices. Site-specific projects represented one of the key strategies for the reconquest of war-devastated public space, while "new" art practices in public space were a priori aimed against institutionalization of art which occurred in the post-war period. 